\title{
DEHÜMANIZASYONUN GÖLGESINDE, KORPORATIZMIN HIZMETINDE BIR POSTHÜMANIZM VIZYONU: ROBOCOP
}

\author{
A Posthuman Vision in the Shadow of Dehumanisation, at the Service of \\ Corporatism: RoboCop
}

\section{Cenk TAN*}

\section{öz}

Paul Verhoeven'ın 1987 yapımı RoboCop filmi, çok katmanlı sosyo-politik yapısıyla popüler kültür ikonu olmayı başarmış bir bilimkurgu yapımıdır. RoboCop, geniş yelpazede sosyal meselelere değinen, dönemin popüler bilimkurgu örneklerinden biridir. Bu çalışma, RoboCop sinema filmini üç temel başıı olan: dehümanizasyon, teknokapitalist korporatizm ve posthümanizm başlıkları altında tartışmaktadır. Makalenin ilk bölümünde Alex Murphy'nin yaşamış olduğu dehümanizasyon süreci ve bunların filmde taşıdığı önem Hannah Arendt'in fikirleriyle aydınlatılmaktadır. Akabinde Alex Murphy'nin, RoboCop'a dönüşümü sonrasında, onun kendi içinde giriştiği mücadele kapsamında tekrar Murphy kimliğini benimsemesi ve yaşamış olduğu üç evreli dönüşüm, filme yapılan göndermelerle ayrıntılı biçimde irdelenmektedir. Makalenin son bölümünde ise RoboCop'un merkezinde yer alan teknokapitalist korporatizm olgusu ile bağlantı kurularak, bu olgunun yapımda sahip olduğu önem ve RoboCop siborgu ile ilişkisi açığa çıkarılmaktadır. Bu kapsamda, çeşitli filozof ve kuramcılardan yararlanılmıştır. Sonuç bölümünde ise RoboCop'un posthümanizm bağlamında ortaya koyduğu insanlık eleştirisi ve ona alternatif olarak sunulan siborg figürü, yapımcı Verhoeven tarafından filmin alt metninde yapılan göndermelerle açığa çıkarılmaktadır.

Anahtar Sözcükler: dehümanizasyon, posthümanizm, RoboCop, siborg, teknokapitalist korporatizm.

\section{ABSTRACT}

Paul Verhoeven's RoboCop (1987) is a work of science fiction which has succeeded to become a popular culture icon with its multi-layered sociopolitical structure. RoboCop is a primary example of science fiction that addresses a wide variety of social issues of its period. This study aims to analyse RoboCop under three main headings: dehumanisation, technocapitalist corporatism and posthumanism. In the first section of the article, Alex Murphy's process of dehumanisation and its signifi-

\footnotetext{
* Dr. Öğretim Görevlisi. Pamukkale Üniversitesi, Yabancı Diller Yüksekokulu, Denizli/Türkiye. Eposta: ctan@pau.edu.tr. ORCID ID: 0000-0003-2451-3612.
} 
cance in the film is enlightened with the theories of Hannah Arendt. Next, Murphy's transformation to RoboCop and the acceptance of his true identity through an inner struggle is revealed in detail with particular references to the film. In the final section of the article, the importance of technocapitalist corporatism which stands at the centre of RoboCop is exposed along with its relation to the cyborg. Within this context, various philosophers and scholars are referred to in the study. In the conclusion, the criticism of humanity and the alternative proposed to it in the form of a cyborg are unveiled with specific references implied by Verhoeven in the subtext of the film.

Keywords: dehumanisation, posthumanism, RoboCop, cyborg, technocapitalist corporatism.

\section{Giriş: Zamanın Ötesinde Bir Yapım Olarak RoboCop}

1987 yılında Hollandalı yönetmen Paul Verhoeven yönetmenliğinde ilk kez yayınlanan RoboCop, başarılı bir bilimkurgu filmi ve popüler kültür ikonu olarak hafızalara kazınmıştır. Sinema, video oyun ve oyuncak sektörlerine önemli bir etkide bulunmakla birlikte, film müziği, replikler ve karakterizasyon anlamında sinemada yer edinmiştir. Her ne kadar 1990 ve 1993'te devam filmleri çekilmiş olsa da bunlar ilk RoboCop filmi ile aynı başarıyı yakalayamamıştır. Uzun bir aradan sonra yeniden yapımına başlanan film, 2014 yılında tekrar izleyicilerle buluşmuş ancak beklenen ilgiyi görmemiştir.

RoboCop, kısaca "siborg"1 olarak adlandırılan sibernetik organizmanın bir temsilcisidir. Siborglar, teknoloji yoluyla hayata döndürülmüş organizmalardır yani başka bir deyişle insan ve makineden oluşan varlıklardır. İnsan gelişimi göz önüne alındığında siborg kavramı, ilk bakışta devrim niteliğinde bir yeniliği temsil etmektedir. RoboCop, fiziksel anlamda bir siborg olmakla birlikte, mental anlamda insansı özelliklere de sahiptir. RoboCop'u, RoboCop yapan yegâne özellik de aslında tam olarak budur. Onun, siborg olarak ne kadar güçlü olduğu, ne kadar isabetli atışlar yapabildiği veya bir polis olarak ne kadar etkili olduğundan ziyade, yeri geldiğinde insan gibi davranabilmesi ve eleştirel düşünme becerisini göstererek kritik kararlara imza atabilmesi onu özel kılan esas unsurdur. Fiziksel anlamda insandan siborga dönüşen Alex Murphy'nin mental olarak ise insan-makine-siborg döngüsünü tamamladığını görebilmekteyiz.

\footnotetext{
${ }^{1}$ Cyborg: cybernetic organism. Edebiyatta ya da sinemada fark etmeksizin, bilimkurgu türü, siborgu insan, bilim ve teknolojinin karışımı bir varlık olarak ele almaktadır ve bu varlık insansonrası çağa aittir (Sobchack, 1997).
} 
Bu makale, sosyal bir posthümanizm anlatısı olan RoboCop filmini farklı açılardan ele almayı hedeflemektedir. Bu bağlamda felsefe, siyaset ve edebiyat teorisi gibi farklı disiplinlere ait kuramlara başvurulmaktadır. Bunun gerekliliği ise RoboCop filminin çok katmanlı ve derinliğe sahip yapısından kaynaklanmaktadır. Bu yüzden makale, RoboCop yapımını üç ana başlık olan: dehümanizasyon, teknokapitalist korporatizm ve posthümanizm altında tartışmaktadır. Geleneksel bir süper kahraman filminin ötesine geçen RoboCop, 1980'lerin ABD'sine dair ciddiye alınması gereken bazı sosyal eleştirilerde bulunmaktadır. Bu eleştiriler Avrupalı bir yönetmenin gözünden yapılmakta ve onun, dönemin ABD'sini nasıl gözlemlediğiyle yakından ilişkilidir. RoboCop aksiyon, kurgu, karakterizasyon ve sosyal eleştiri gibi unsurların tamamını bütünsel olarak doyurucu bir şekilde kapsamaktadır.

Ayrıca, bu makale sadece RoboCop (1987) serisinin ilk filmini temel almaktadır ve devam filmlerini $(1990,1993,2014)$ kapsam dışı bırakmaktadır. Bunun sebebi ise oldukça nettir. Çekilmiş olan dört film içinde kurgusu ve alt-metninde bulunan ince referanslarla sağlam bir zemine oturtulmuş olan tek film, serinin başlangıcı olan 1987 yapımıdır. Makale, kapsamını sınırlandırmak adına başlangıç filmi olan RoboCop yapımını merkeze alarak, buna ilişkin sorunsalları tartışmakta ve önemli hususları açığa çıkarmaktadır. Bu bağlamda makale, dehümanize edilen memur Murphy'nin, RoboCop kimliğiyle bir siborg olarak diriltilmesini ve insanlığa bir alternatif olarak var oluşunu ancak bu alternatifin muhalifi olduğu teknokapitalist korporatizmin egemenliğinde kalmasını tartışmaktadır. Insan sonrası bir varlık olan RoboCop, bu anlamda korporatist hegemonyanın karşısında yetersiz kalmaktadır çünkü sahip olduğu tüm imkânlara rağmen sistemle mücadele etmede ona yenik düşmektedir.

\section{Murphy'nin Dehümanizasyonu ve Siborg'un Yaratılışı}

RoboCop'un başlangıç sahnesinde nispeten sakin bir yerleşimden suç oranı ürkütücü derecede yüksek bir şehir olan Detroit'e tayin edilen polis memuru Alex Murphy ilk defa izleyicilere takdim edilmektedir. Bir aile babası olduğu ortaya çıkan Murphy, çalışkan ve idealist bir polis memurudur ancak Detroit gibi kontrolden çıkmış bir yerde görev yapacak tecrübe ve bilgiye sahip değildir. Yeni görev yerine atanan memura ne oryantasyon verilir ne de bir brifing. Polis memurları fazla mesai yapan, emeğinin hakkını alamayan ve greve gitmek isteyen belirsiz bir ortamın içerisindedirler. Memur Murphy bu görev için tamamen hazırlıksızdır ve tüm bu etkenlere rağmen, ilk günden sahaya sürülür. Teşkilatta kıdemli ve şehirde tecrübe sahibi olan memur Anne Lewis ile partner olur. Alex, karakter olarak maceraperest, gö- 
zü kara ve aşırı idealist bir yapıya sahiptir. Öyle idealisttir ki, henüz doğru düzgün tanımadığı bir şehirde ilk günden çıktığı görevde, kırmızı bültenle aranan ve şehrin en tehlikeli suçluları olarak bilinen "Boddicker çetesinin" peşine düşer. Adeta bir deli cesaretiyle suçluların üzerine giden Murphy, çete tarafından yakalanarak barbarca öldürülür. Temkinli davranan partneri Lewis ise ortaya çıkan vahşeti gözleri önünde izlemekle yetinir.

"Dehümanizasyon"2 kavramının sabit bir tanımı olmamakla birlikte, kavram günümüze dek farklı biçim ve bağlamlarda yorumlanmıştır. Dehümanizasyon en temel anlamda, bir kişi veya grupta bulunan insan olmanın ret edilmesidir. Buna ek olarak dehümanizasyonun farklı dereceleri mevcuttur; bunlar ılımlı ve ekstrem dehümanizasyon olarak sınıflandırılmaktadır (Oliver, 2010: 86). Ekstrem örneklerde işkence ve soykırım gibi eylemler gözlenirken, ılımlı örneklerde ise sosyal, siyasal ve ekonomik anlamda marjinalleştirme durumları görülmektedir (2010: 86-87). Dolayısıla, herhangi bir bireye ya da gruba, insan haysiyetinden yoksun bırakacak şekilde davranışlar sergilemek -en ılımlıdan, en şiddetli ve barbarca olana kadar- dehümanizasyon kapsamına girmektedir. Böylece dehümanizasyona uğrayan birey, insan haysiyetinden yoksun bırakılarak, insan dışı bir muameleye maruz kalmaktadır. Dehümanizasyon, küçük düşürme, aşağılama ve hakaret etme gibi davranışlarla da işlevsellik göstermektedir (2010: 89). Nick Haslam, kişilere insanlık dışı davranışlar sergilemeyi "hayvansı metafor" (animalistik metaphor) olarak nitelendirmiştir (2006: 257). Bu bağlamda kurbanlar, insani özelliklere sahip olmadıkları düşüncesiyle, insanlık dışı bir muameleye layık görülmektedir. Bundan dolayıdır ki dehümanizasyon, "insanların zulüm edenlerin kitlesel ölçekte cinayet işlemesine ve çevredeki kişilerin itirazsız veya pişmanlık duymadan beklemelerine olanak tanıyacak kadar radikal bir şekilde farklı kılınması sürecidir." (Oliver, 2010: 89). Eski bir Nazi SS Subayı olan Franz Stangl, kamplarda ${ }^{3}$ uyguladığı dehümanizasyon vahşetini şöyle açıklıyor:

Hepsini öldüreceğini göz önüne aldığımızda, onları aşağılamanın ve yapılan zulümlerin amacı neydi? (...) Operasyonların maddi uygulayıcısını şartlandırmak. Yapacakları zulümleri mümkün kılmak için diye cevap verir Stangl. Başka bir deyişle: katilin suçluluk duygusuyla daha az yüklenebilmesi için ölmeden önce kurban aşağılanmalıdır. Bu mantıktan yoksun değil, cennete haykıran bir açık-

\footnotetext{
${ }^{2}$ Türkçeye "insandışılaştırma" olarak da çevrilmiştir.

${ }^{3}$ Solibor ve Treblinka Konsantrasyon Kampları.
} 
lamadır: yararsız şiddetin yegâne faydası budur (Levi, 1989: 100101).

Siyaset bilimci ve filozof Hannah Arendt'in tezine göre modern yaşamda çalışma tüm diğer etkinliklere egemen olmuş ve onları absorbe etmiştir (Scanlan, 1960: 299). İnsan bir "çalışan hayvan" (animal laboran) ve toplum ise bir tüketici toplumu halini almıştır. Bu ortamda emek ve çalışma değerini büyük oranda kaybetmiştir ve bu yüzden emekçiler bir tüketim ürünü olarak görülmeye başlanmıştır (1960: 300). Arendt'e göre en ürkütücü toplum modeli, çalışmadan başka bir etkinlik bilmeyen bir toplum modelidir ve buna bağlı olarak çalışan hayvan kavramı, hayatını idame ettirebilmek için tüm gücünü ve zamanını çalışmaya vermiş emekçileri tarif etmektedir. Ayrıca entelektüel etkinlikler o denli yozlaşmıştır ki artık özgür olmakla olmamak arasındaki fark anlaşılmaz hale gelmiştir (1960: 301).

RoboCop'ta polis teşkilatı yozlaşmış, kaynakları asgariye düşürülmüş ve artan suçla baş edemez hale geldiği için yönetimi özel bir girişim olan OCP ${ }^{4}$ şirketine devredilmiştir. Şirket, polis memurlarını dilediği gibi işten çıkarmakta, yerlerini değiştirmekte ve teşkilatı adeta sıradan bir şirketmiş gibi yönetmektedir. Bu esnada memurlar aşırı mesai yapmakta, iş güvenceleri ellerinden alınmakta ve her geçen gün daha fazla hayati tehlikeye maruz kalmaktadırlar. OCP ise polis teşkilatına bir tür varlık gözüyle bakmakta ve birimi kendi projelerine denek olarak kullanmayı amaçlamaktadır. Bu amaç doğrultusunda gereken her şeyi yapmaya hazır olan şirket, insan hayatını hiçe saymaktadır. Bu bağlamda RoboCop'ta polis memurları çalışan birer hayvan konumundadır çünkü hayatta kalabilmek için çalışmaktan başka çareleri yoktur. Çalışma eylemi bu durumda, tüm diğer eylem ve etkinliklerin önüne geçmektedir. Bu noktada çalışma, tüm diğer intiyaç ve etkinlikleri önceleyen, zorunlu bir gereklilik halini almıştır. Özelleştirilen Detroit polis teşkilatında memurlara OCP tarafından dayatılan çalışma koşulları bir dehümanizasyon örneğini teşkil etmektedir. Memurlar, artan suç ve kötüleşen çalışma koşulları içerisinde ezilmektedir ve şehri teslim almış terör karşısında yalnız ve çaresiz bırakılmaktadır. Bu noktada polis memurlarının grev yetkisi ellerinden alınmış, böylece protesto hakları şirketçe gasp edilmiştir. Tüm Detroit polis teşkilatı, yozlaşmış ve çürümüş bir bataklığın içine çekilmiş ve memurları çalışan hayvan konumuna indirgenmiştir.

Alex Muphy'nin ilk dehümanizasyonu dolaylı biçimde hizmet ettiği şirket yoluyla meydana getirilmektedir. Burada dehümanizasyon, çalışma

\footnotetext{
${ }^{4}$ Omni Consumer Products.
} 
koşullarının insanlık dışı seviyelere gelmesinden ve Arendt'in deyimiyle polis memurlarının birer çalışan hayvan konumuna indirgenmeleriyle ortaya çıkmaktadır. Dolayısıyla bu, sosyal ve ekonomik bir dehümanizasyondur ve kölelikten bir önceki aşamayı temsil etmektedir. Çalışan hayvan olgusunun uzun vadede devam etmesi halinde çalışanlar kölelik konumuna indirgenecektir. Bu kölelik türü, korporatist kapitalizm tarafından bireylere dayatılan ve modernite ile süslenmiş bir köleliktir. Murphy'nin ikinci dehümanizasyonu ise fiziksel ve psikolojik olmakla birlikte, ekstrem bir dehümanizasyon örneğini teşkil etmektedir. Murphy, daha ilk görevinde şehrin en tehlikeli çetesine yakalanır ve hunharca katledilir. Önce çete lideri Clarence Boddicker tarafından aşağılanır, ardından bir köpek gibi itilip kakılarak yere serilir ve akabinde eli, kolu koparılacak şekilde vurulur ve son olarak kurşun yağmuruna tutularak alnının ortasına yediği bir mermiyle hayatı sonlandırılır. Bu öldürülme şekli hem fiziksel olarak, hem de sembolik anlamda net bir dehümanizasyon örneğidir. Murphy'nin uzuvlarının koparılarak vahşice öldürülmesi, onun sadece hayattan koparılması değil, insan haysiyetinin elinden zorla alınması anlamına gelmektedir. Onca zahmete gerek duymadan kafasına bir kurşun sıkılarak da aynı sonuca gidilebilirdi ancak çete, tercihi bu yönde kullanmamaktadır.

Dehümanizasyon, bunlara ek olarak bireylerin kimliğini, özerkliğini ve kendi seslerini kaybetmeleri anlamına gelmektedir (Oliver, 2010: 90). Bazılarına göre ise dehümanizasyona uğramak, insan vücudunun ve benliğinin parçalara ayrılması ile ilişkilendirilir. Kurban, sürecin sonunda önceden olduğu kişi değildir, bir vücut parçası, ceset veya bir nesne halini almıştır. Birey olarak bütünlüğü bozulmuş ve parçalanmıştır, bir kişiden nesneye dönüşmüştür (2010: 90). Tüm bunlar Alex Murphy için de geçerlidir. Gaddarca katledilen Murphy'nin uzuvları yerinden koparılmış, bedeni parçalara ayrılmıştır. Artık Murphy olmaktan çıkmış, parçalanmış ve bir cesede dönüşmüştür. Murphy, tıbbi anlamda kurtuluşu mümkün olmayacak şekilde öldürülmüştür. Böylece siborga dönüştürülmesinin altyapısı hazırlanmıştır. OCP karargâhına götürülen Murphy'nin geriye kalan bedenine yoğunlaşan teknisyen ve sözde bilim insanlarının bu esnada yaptıkları yorumlar ise oldukça çarpıcıdır:

Tyler: Sol kolunu kurtarabildik.

Morton: Ne? Bütün vücudun protezi üzerine anlaştığımızı düşünüyordum. Kolu kaybet tamam mı? Ne dediğimi anlayabiliyor mu? Roosevelt: Fark etmez, nasıl olsa hafızasını sileceğiz. 
Morton: Bence kolunu kaybetmeliyiz. Sen ne düşünüyorsun Johnson?

Johnson: Teşkilata girerken devir formlarını imzalamış, yasal olarak o bir ölü. Aslında onunla dilediğimiz her şeyi yapabiliriz.

Morton: Kolu yok et.

Tyler: Tamam, onu kapatın ve ameliyata hazırlayın (Verhoeven, 1987: 26:50).

Sembolik açıdan bakıldığında, her iki dehümanizasyon, çalışan, emekçi sınıfına yönelik kasıtlı ve planlı biçimde gerçekleştirilmektedir. Yine her iki dehümanizasyonun sorumlusu ve faili OCP şirketinin kendisidir. Polisleri insanlık dışı koşullarda çalıştıran ve Murphy'nin cinayetine (ve daha nicelerinin) sebep olan altyapıyı hazırlayan bu şirketten başkası değildir. Emniyet birimleri, tüm yönetici kadrosuyla birlikte bu cinayetin iş birlikçileri pozisyonundadır. Polisleri kendi elleriyle OCP'ye teslim eden Detroit Polis Teşkilatı, tüm gidişattan ve olacaklardan en az şirketin kendisi kadar sorumluluk sahibidir. Emekçi emniyet çalışanları ise bu süreçte tamamen yalnız kalmış ve kaderleri OCP şirketinin insafına bırakılmıştır. Her iki dehümanizasyon örneğinde çalışan emekçiler insan yerine konmamış ve insani değerlerden alenen koparılmışlardır. RoboCop'ta görülen değersizleştirme algısı sadece çalışan emekçilere yöneliktir çünkü şirketin gözünde onların kıymeti yoktur. Hayatlarını kaybetseler dahi, yerleri kolayca doldurulabilecektir. Bu yüzden gözden çıkarılabilir ve en harcanabilir kesim konumundalardır. Dehümanizasyonun RoboCop'taki asıl amacı, özelde Murphy'yi ve genel anlamda polis memurlarını değersizleştirerek, onları insan dışı bir pozisyonda konumlandırmak ve böylece onların rahatlıkla harcanmalarına zemin hazırlamaktır. İşin ilginç tarafı ise polis memurlarının bu acımasız düzen karşısında kendi aralarında dayanışma ve örgütlenme konusunda istenen seviyede olmamalarıdır.

Farklı biçimlerde ve koşullarda meydana gelebilmekle birlikte, dehümanizasyon kavramının teknolojik yeniliklerle doğrudan bağlantısı söz konusudur. Robotik hayali, teknolojiler ve kültürel hayallerin karşısında insanın indirgenemezliğini açığa çıkarmaktadır. Siborglar, dehümanizasyon yoluyla insanın yapısını yansıtan zengin bir inceleme ve spekülatif yeniden yapılandırma alanı sunmaktadır (Rhee, 2018: 5). Bu kapsamda dronlar da siborg benzeri bir örnek olarak verilebilmektedir. İnsansız hava aracı olan dronlar, ırksal dehümanizasyonun bir aracı haline getirilmiştir. Dronların saldırı ve öldürme kabiliyeti, geniş bir bağlamda dehümanizasyon ve ırksal ayrımcılıkla yakından ilişkilidir ve ABD, dron mahkemelerinin sadece Amerikan va- 
tandaşlarının hedefe alınması durumunda göreve çağırılacağını ifade etmiştir (2018: 134-135). ilk silahlı dron saldırısı ABD tarafından 2001 yılında Afganistan'da gerçekleştirilmiştir ve o günden bu güne dron saldırılarında ciddi bir artış gözlenmiştir (2018: 137). Silahlı dronlar tarafından vurulan insan sayısı konusunda bir mutabakat bulunmamaktadır. Aksine dair kanıt sunulmadığı takdirde ABD, denizaşırı topraklarda dron saldırısı sonucunda ölen her askerlik çağındaki erkeği bir düşman unsur olarak kabul etmektedir ve ayrıca öldürülen insanların sivil ya da asker olup olmadıkları yönünde soruşturma yürütmeye yönelik herhangi bir yasal prosedüre de sahip değildir (2018: 138). Bunun sonucu olarak dron teknolojisiyle gerçekleştirilen saldırılar sonucunda bazı yaşamlar insandan sayılmayarak dehümanize edilmiştir.

Siborgların, toplumda yaygınlaşmaları durumunda ırksal, sınıfsal ve ideolojik ayrımcılığa aracı olarak hizmet etmeleri ve yazılımlarının karşı tarafla mücadele ve çatışmaya girişecek şekilde programlanmaları kaçınılmaz bir durumdur. Dron örneğinde olduğu gibi, siborglar da benzer amaçlar uğruna kullanılabilecektir. Siborg kavramını ilk defa ayrıntılı biçimde tasnif eden yazar Donna Haraway, onlar hakkında şu sözleri sarf etmiştir: "kapitalizmin gayri-meşru evlatlarıdır fakat gayri-meşru evlatların kendi kökenlerine karşı genelde aşırı vefasızca davrandıkları da bilinmektedir. Her şey bir yana, babalarının hayatlarında hiçbir yeri yoktur çünkü” (2006: 7). Haraway'in bu ifadesi RoboCop için bire bir geçerli ve isabetli bir ifadedir. RoboCop, OCP'nin gayri-meşru çocuğu olarak dünyaya getirilmektedir. Onun yaratılması planlı ve bilinçli bir tercihten ziyade, uzun deneme ve yanılmalar sonrası gerçekleşen olaylar zincirinin sonucu olarak meydana gelmektedir. RoboCop'un yaratıcısı OCP ile olan ilişkisi filmin geneline hakim olan ironiyi açığa çıkarmaktadır. RoboCop'un yaratıış amacının dışına çıkması ve zamanla yaratıcısına ters düşmesi siborg doğasına uygun olarak gerçekleşmesi muhtemel bir durumdur. Haraway siborglar hakkında şu ifadeleri kullanmıştır:

Bir siborg, bir sibernetik organizma, makine ile organizmanın oluşturduğu bir melez, kurgusal bir yaratık olmanın yanı sıra toplumsal gerçekliğe ait bir yaratıktır. Toplumsal gerçekliğin karşıı̆ı, canlı toplumsal ilişkilerdir; bu da bizim en önemli siyasal kurgumuz, dünyayı değiştiren bir kurgudur. Kadın deneyimi, hayati önemde ve siyasal nitelikte bir kurgu ve olgudur. Kurtuluş ise ezilmişliğin ve buna bağlı olarak intimallerin farkında olan bir bilincin, tahayyülü geniş bir kavrayış gücünün kurulmasında yatar. Siborg, yirminci 
yüzyılın son döneminde 'kadın deneyimi' sayılan olguyu değiştiren bir kurgu ve canlı deneyim meselesidir (2006: 2-3).

Haraway, yazmış olduğu bu eserde, siborgların çerçevesini çizmekle birlikte, onları geleneksel ataerkil batı kültüründen farklı bir yerde konumlandırmış ve cinsiyetsiz varlıklar olduklarını öne sürmüştür. Dolayısıyla, siborgların, Batı kültürüyle ilişkilendirilen ataerkil ve baskıcı değerlerden bir kopma eğilimini temsil ettiklerini ifade etmiştir. Böylece, siborglara olumlu bazı değerler atfetmekle birlikte, onların temsil ettiği kapitalist, ataerkil kökeni de vurgulamaktan geri kalmamıştır. Yaratıcısının suretine ve ruhuna uygun olacak şekilde RoboCop'a erkeksi ve iri yarı bir görünüm sağlanmıştır ancak bu noktada sorumluluk siborgun kendisinden çok onu yaratana aittir. Şu bir gerçektir ki, RoboCop'un erkeksi ve kaslı görünümünün arkasında Haraway'in tarif ettiği cinsiyetsiz bir varlık bulunmaktadır. RoboCop, kadın erkek, siyah beyaz, zengin fakir gibi düalist ve hiyerarşik ayrımlardan tamamen arınmış bir varlık olarak varlık göstermektedir. Bu anlamda insan türü ile belirgin farklılıklara sahip olduğu ileri sürülebilecektir. Bu bağlamda, RoboCop, Haraway'in ifade ettiği siborg tanımına ilişkin bir örneğin temsilcisidir:

Bu siborg bizim ontolojimizdir; bizim siyasetimizi o şekillendirir. Siborg, köklü tarihsel dönüşüm intimallerinin yapıtaşları olan iki birleşik merkezin, hem 'tahayyül 'ün hem de 'maddi gerçeklik 'in yoğunlaşmış bir imgesidir. Batı’nın bilim ve siyaset geleneklerinde organizma ile makine arasındaki ilişki, hep bir sınır muharebesi şeklinde cereyan etmiştir. (...) Dolayısıyla siborg muhaliftir, ütopyacıdır ve masumiyetle hiç alakalı değildir. Yapısı artık kamusal/özel karşıtlığıyla belirlenmeyen siborg, kısmen oikos yani hanede gerçekleşen bir toplumsal ilişkiler devrimine dayalı bir teknolojik polisi tanımlar (2006: 4-6).

Paul Verhoeven'ın RoboCop'u en başından sonuna kadar dikkatlice kurgulanmış bir ironiler bütününü temsil etmektedir. Kurulan diyaloglar, aşırı şiddet içeren sahneler ve RoboCop'un ortaya çıkış süreci başlı başına birer ironi örneğidir. $O$, yaratıcısına hizmet etmek amacıyla tasarlanmış bir varlık olsa da, OCP'nin antitezinin açık bir tasviridir. Bu bağlamda OCP ve onun yetkilileri RoboCop ve onun siborg kimliğini idrak edebilme noktasından uzak bir konumdadırlar. Bu yüzdendir ki ona diğer makinelerden farksız bir şekilde davranmakta ve onu hedeflerini elde etmede kullanacakları bir araç olarak görmektedirler. Ancak gerçekte durum oldukça farklıdır çünkü RoboCop, OCP'ye muhalif değerleri içselleştiren, ütopyacı bir yapıya sahiptir. 
Başka bir deyiş̧le, RoboCop'un polisliğiyle, mesleki yönüyle sınırlı kalmamakta ve toplumsal polisliğin tasvirini de ortaya koymaktadır. Gunkel'e göre siborg: "insan kavramının ve tanımının erozyona uğramasının ürünüdür. Bu erozyon, kategorik bir ayrımın şartları arasındaki iletişimi teşvik ederek, birinin diğeri tarafından tamamen kirlenmesine neden olur. Bu nedenle, siborg ne insandır ne de diyalektik olarak karşıt olan ötekidir" (Gunkel, 2000: 335). Sembolik bağlamda RoboCop'un ortaya çıkışı bu insanlık erozyonundan kaynaklanmaktadır. RoboCop, ötekileştiren, ezen, sömüren, yok eden, erozyona uğramış insanlığa bir alternatifi simgelemektedir.

\section{Teknokapitalist Korporatizm: RoboCop Kimin Hizmetinde?}

RoboCop filmi 1980'lerin ABD'sini tasvir etmekle birlikte, onu Avrupalı bir yönetmenin gözünden yansıtmaktadır. 1980'lerde "Reaganomics" olarak bilinen, başkan Ronald Reagan'ın uyguladığı neo-liberal politikalar ile Amerikan ekonomisine ivme kazandırma amacı güdülmüştür. Bu kapsamda özel sektör desteklenmiş, kamu harcamaları asgariye indirilmiş ve devlet düzenlemeleri en düşük seviyelerde tutulmuştur. Bu dönemin ekonomiye olan etkileri günümüzde halen tartışılmaktadır. 1987 yılında yayınlanan RoboCop filmi tam olarak bu dönemi yansıtmaktadır. Her köşeye bir alışveriş merkezinin açıldığı, büyük holdinglerin ve onların başındaki kapitalistlerin egemenlik kurduğu ve kamu düzeninin asgari seviyelere çekildiği bu dönem, filmde Paul Verhoeven'ın kendine özgü, ironik ve esprili bakış açısıyla tasvir edilmektedir. Filmin başlangıcında Detroit şehrinde suç tavan yapmış, maddi anlamda yetersiz destek gören kamu kurumları ise bununla baş edemez hale gelmiştir. Bunların başında Detroit polis teşkilatı gelmektedir. Tam bu noktada devreye OCP girmiş ve polis teşkilatını fonlayarak, bütün yönetimi ele almıştır.

OCP şirketi Detroit polis merkezine egemen olduktan sonra, onu adeta bir şirket kolu gibi görmüş ve kendi öz çıkarları doğrultusunda kullanmaya başlamıştır. Bunu yaparken ise sadece kendi çıkarlarıyla, geleceğini düşünmüş ve tüm diğer unsurları göz ardı etmiştir. Korporatist bir mantalite ve örgüt yapısına sahip olan OCP, RoboCop’ta varlığı belirsiz olan devleti temsil etmektedir. OCP devletin yerine geçen güç konumundadır ve bu, problem teşkil eden bir durumdur. Devletin alması gereken tüm kararları OCP almakta, kamu yararı gözetilmesi gereken tüm alanlarda şirketin çıkarları ön plana geçmektedir. Açıkça görülmektedir ki, OCP hem devleti hem de çok uluslu şirketlerin egemenliğini temsil etmektedir. Bu noktada film, gelecek toplumlarının çok uluslu şirketlerin kontrol ettiği devlet aygıtlarını ve onların bürokratik işleyiş̧inin bilgisayarlara, yapay zekâya ve siborg varoluşuna 
aşamalı olarak geçmekte oluşunu göstermektedir. Sonuç olarak, Detroit şehri ve onun yerel halkı veya toplumun geneli için olumlu neticelerin çıkması düşük bir olasılıktır çünkü şirketin genel mantalitesi kar odaklı olmakla birlikte, topluma ya da bireylere hizmet etme anlayışından uzak bir noktada bulunmaktadır. Filmin en başında polis memurları kötü çalışma koşullarından dolayı grev kararı almak istemektedir ancak bırakın kararı, grevin konuşulması dahi OCP ve işbirlikçileri için son derece rahatsızlık vericidir:

Ne yapmamız gerektiğini söyleyeyim. Greve gitmeliyiz. Cenaze yarın yapılacak. Teşkilat görevde olmayan tüm memurların katılımını bekliyor. Aile için yapılacak bağışları her zamanki gibi Cecil toplayacak. Bir daha grev hakkında konuşulmasını istemiyorum. Bizler su tesisatçısı değil, polis memuruyuz ve polis memurları greve gitmez (Verhoeven, 1987: 04:35).

Memurlara bu sözleri sarf eden Polis teşkilatı müdürü çalışanların temel hakkı olan grev hakkını ellerinden alan OCP'nin yanında saf tutarak, grev eyleminin polislerde kesinlikle yerinin olmadığını sert bir dille ifade etmektedir. Esasında, memurların grevi dillendirmeleri, insanca çalışma koşullarına sahip olmak istemelerinden kaynaklanmaktadır. Ancak azami kar etmeyi ve çalışanları sömürmeyi hedefleyen OCP için insanca çalışma koşulları bile uygunsuz ve kabul edilemez görülmektedir. Bu bağlamda, Deleuze ve Foucault'nun vurgulamış olduğu disiplin toplumlarından denetim toplumlarına doğru kademeli bir geçiş söz konusudur. Deleuze, disiplinden sonra kaçınılmaz olarak denetim aşamasının geleceğini ifade etmektedir (Kelly, 2015: 159, 152). RoboCop filminde benzer bir durum söz konusudur. Polis memurları önce olumsuz çalışma koşulları ile disipline tabi tutulur, akabinde ise OCP'nin yaratmış olduğu teknolojik projelerle polis teşkilatının üzerinde mutlak bir denetim sağlamayı hedeflemektedir. Kendi aralarında konuşan OCP yöneticileri grev konusu hakkında şöyle söylemektedir: "onlar devlet memuru. İ̧̧ güvencesine sahipler. Greve gitmemeliler. Burası özgür bir toplum ancak hiç bir şey özgür değil çünkü hiçbir şeyin garantisi yok. Kendi başınasın, doğanın kanunu bu" (Verhoeven, 1987: 1:16:47). Her ne kadar polis sendikası grev kararı almış olsa da, (bir haftada beş memur ölmüştür) OCP bu kararı uygulatmamak için içeriden ve dışarıdan elinden geleni yapacaktır ancak buna rağmen birimin yarısı akşam olduğunda görev yerine gitmeyecektir. Günümüzde görülmektedir ki, gelişen robotik ve yapay zekâ teknolojilerine de bir takım hakların verilmesi tartışılmaktadır. Robotların da insanlar gibi kimlik sahibi olması, gelecekte onlara ve yapay zekâlara maaş bağlanması gibi hususlar Avrupa ülkelerinde tartışılmaktadır. Bu bağlamda, 
"RoboEtik" terimi ilk kez resmi olarak Japonya'da, Fukuoka Dünya Robot Bildirgesinde kullanılmıştır (Yigit vd., 2018: 34). Söz konusu bildirgeye göre:

1. Gelecek nesil robotlar insanlarla beraber yaşayan sıradan varlıklar olacaktır. 2. Gelecek nesil robotlar insanlara fiziksel ve psikolojik olarak yardım edecektir. 3. Gelecek nesil robotlar güvenliğe ve barışçıl topluma katkı sağlayacaktır (2018: 34).

Öte yandan, robot ve yapay zekâ teknolojilerinin insan istihdamında yaratacağı olumsuz etkiler şimdiden derin kaygılara ve bazı ülkelerde protestolara varan tepkilere sebep olmaktadır. 2015 yılında ABD'nin Austin kentinde SXSW Tech Eğlence Festivalinde bir bilgisayar mühendisinin önderliğinde yapay zekâ ve robotlara yönelik bir protesto gerçekleştirilmiştir (Swartz, 2015). "Robotları Durdurun" ve "insanlar Gelecektir" gibi pankartlar taşıyan protestocular arasında Texas Üniversitesi mühendislik öğrencilerinin olduğu bilinmektedir. Evernote firmasının CEO'su Phil Libin, "insanlar robotların dünyayı ele geçirmesinden endişeleniyorlar fakat size küresel ısınma ve gelir adaletsizliği gibi çok daha önemli problemlerin olduğunu söyleyebilirim. Insanlar başka insanlardan daha çok endişelenmelidir" sözlerini sarf etmiştir (Swartz, 2015).

Adil bir toplumun temel hedefi özgürleşmeyi sağlamaktır ve özgürleşme sadece baskıcı ve sömürücü koşullardan kurtulmak değil, toplum yönetimine ve onun tüm alanlarındaki yaratıcı etkinliklerine katılımı gerçekleştirmeyi ifade etmektedir. Bu bağlamda özgürleştirici katıım her zamankinden daha çok insan olmayı tanımlayan kararları içermekte ve bunları teknolojik yaratıcılıkla birleştirmektedir ancak bu kararlar çoğunlukla korporatizm ve onun teknolojinin üzerindeki otoriter gücü tarafından belirlenmektedir (Suarez-Villa, 2012: 1). Korporatizm, büyük sermayeli şirketlerin toplum üzerinde sahip olduğu güç olarak tanımlanmaktadır. Terimin tek bir tanımı olmamasına karşılık, çok geniş bir kapsamı vardır. Genel anlamda ise, şirket gücünün toplumun doğası ve yönetimi üzerinde sahip olduğu geniş yetki alanını içermektedir (2012: 2). Korporatizmin olası bir tanımı şöyledir:

Insan toplumunu, doğayı ve gezegeni kolonileştirirken, korporatizm bizi aşağılayarak en değerli insani niteliklerimizi metalara (commodity) dönüştürür. Böylece yaratıcılığımız, bilgimiz ve öğrenmemiz özgürleştiren nitelikler değil, bizi insanlıktan, toplumdan ve doğadan yabancılaşmamıza bağlayan metalar haline gelmektedir. İnsani değerlerin bozulması, başlı başına teknolojiye dayan- 
mamaktadır. Yeni bir tür korporatizm karakterine ve teknoloji üzerindeki otoriter kontrolüne dayanmaktadır (Suarez-Villa, 2012: 2).

Söz konusu yeni korporatizm, eskisine göre çok daha zeki, saldırgan ve yırtıcıdır. Bundan dolayı, insanın özgürleşmesini sağlamak amacıyla sosyal bir bilincin yaratılması gerekmektedir. Teknoloji, insan eylem ve kararlarının bir sonucu olarak ortaya çıkmaktadır ve bu kararların sosyal, siyasal ve ekonomik boyutları bulunmaktadır. Korporatizmin yaratmış olduğu bir alt kavram olan teknokapitalizm ise ağırlıklı olarak korporatist güce ve teknolojik yaratıcılığa dayanan yeni kapitalizm türü olarak tanımlanmaktadır (2012: 3). Bu kapsamda kıymetli bir değer olan insan yaratıcılığı metalaştırılmakta ve yeniliklerle, icatlar yoluyla sömürülmektedir. Sonuç itibariyle teknokapitalizm, korporatist bir ürün olarak egemen sermaye sınıfının sömürü ve baskı düzenini hızlandırmayı, kolaylaştırmayı ve teknoloji aracılığıyla daha etkin kılmayı amaçlamaktadır. Öyle görülmektedir ki, teknokapitalist korporatizm, gelecekte yapay zekâ tasarımcılarının ve kod yazıcılarının egemenliğinde olacaktır. Dolayısıyla, bu unsurları kontrol eden korporatist yapıların, toplumların üzerinde ciddi bir hâkimiyet sağlayacağını öngörmek şimdiden mümkündür.

RoboCop, teknokapitalist korporatizmin bir ürünü olmakla beraber korporatizmin teknoloji üzerinde kurmuş olduğu egemenliğin simgelerinden biridir. Üstün bir teknoloji ve yaratıcılıkla meydana getirilen siborg, ilk aşamada bulunduğu şehir ve toplum için kusursuz bir izlenim vermektedir. Peki, RoboCop gerçekte hangi amaç için yaratılmıştır ve polislerin geleceği açısından ne ifade etmektedir? Bu soruların yanıtları, RoboCop'ta büyük resmi görebilmek için önem arz etmektedir. Şu bir gerçektir ki, OCP, RoboCop projesini polis teşkilatının işini kolaylaştırmak veya suç oranını düşürmek için yaratmamıştır. Özünde bir denek görevini üstlenen RoboCop, OCP’ye servet kazandıracak bir mega projedir. Siborglar belki de şehirleri suçtan temizleyecekler ancak gelişmiş teknolojik özelliklerinden dolayı bir siborg, beş-altı polis memurunun yaptığını tek başına yapabilecek, OCP böylece az sayıda siborgla büyük bir bölgeyi kontrol altında tutabilecektir. OCP somut anlamda, Detroit'un merkezine "Delta City" adında yeni bir şehir kurarak, eski Detroit'u silmek istemektedir. Bunu gerçekleştirmek içinse iki milyon işçiye intiyaç vardır ancak dibe kadar suça batmış bir şehirde bu mega projenin tamamlanabilmesi için öncelikle işçilerin güvenliğinin sağlanması gerekmektedir. Bunun için de yemeden, içmeden, uyumadan ve asla yorulmadan çalışacak polislere ihtiyaç duyulacaktır. RoboCop'a duyulan ihtiyacın pragmatik nedenleri böylece açığa çıkmaktadır. 
Fransız filozof, Louis Althusser'e göre üretim ilişkilerini şekillendiren iki unsur bulunmaktadır: baskıcı devlet aygıtı (repressive state apparatus) ve ideolojik devlet aygitı (ideological state apparatus) (Althusser, 2014: 1-2). Baskıcı devlet aygıtını Kant'ın kanun anlayışıyla temellendiren Althusser, buna göre kanunun kısıtlama gerektirdiği sonucuna varmıştır. Kısıtlama, yaptırıma ve yaptırım da baskıya yol açmaktadır. Bu yüzden baskıcı devlet aygıtları olarak tanımlanan unsurlar, kanunlara tabi olan mahkeme, silahlı kuvvetler, emniyet güçleri ve diğer devlet kurumlarından oluşmaktadır (2014: 65-66). Bunları ideolojik devlet aygıtlarından ayıran en önemli unsur ise doğrudan ya da dolaylı biçimde fiziksel şiddete başvurmalarıdır (2014: 78). Baskıcı devlet aygıtlarının dayandıkları ideolojik temeller ise legal ideoloji olarak adlandırılmaktadır (2014: 67).

RoboCop'ta Detroit polis teşkilatı baskıcı bir devlet aygıtını temsil etmektedir ancak buna ilişkin büyük bir problem söz konusudur. Doğrudan devlet otoritesine bağlı olması gereken polis birimi, filmde yasal olarak olmasa da, de fakto olarak özelleştirilmiş ve korporatist bir yapı olan OCP'ye devredilmiştir. Böylece, demokratik bir sistem içerisinde seçilmiş veya atanmış kamu görevlilerinin idaresinde olması beklenen bir emniyet birimi, korporatist bir yapının insafına teslim edilmiştir. Bunun doğal sonucu olarak, filmde baskıcı devlet aygıtı tamamen OCP'nin egemenliği altındadır. Şirket istediği gibi kararlar alabilmekte ve kendi ideoloji ve emellerini nüfuz sahibi olduğu toplum alanına rahatlıkla dayatabilmektedir. Bu bağlamda RoboCop'ta mevcut legal ideoloji, OCP tarafından çerçevesi çizilen ve temelleri teknokapitalist korporatizme dayanan bir ideolojidir ve bu ideoloji kendi bünyesinde ahlak, adalet ve sosyal açılardan ciddi sakınca ve problemler barındırmaktadır. Netice itibariyle OCP'nin her daim adaletten yana olacağının bir garantisi yoktur ve istemesi durumunda sahip olduğu yetki ve gücü suiistimal edip, karşısına geçenleri kolayca yok etmesi uzak bir olasılık olmayacaktır. Bu yüzdendir ki, RoboCop'ta teknokapitalist korporatizmin temsilcisi olan OCP, Detroit polis teşkilatını bünyesinde eriterek etkili baskıcı devlet aygıtlarından biri üzerine hâkimiyet kurmuş ve egemenliğini arttırma yolunda sağlam bir adım atmıştır.

Yakın tarihten OCP olgusuna benzer pek çok örnek verilebilmektedir. Buna, ABD'nin Irak savaşında uygulamış olduğu özelleştirme politikaları gösterilebilir. Bu kapsamda ABD için Irak'ta yapılan işlerin yüzde ellisini üstlenen özel girişimler, yemekten, lojistiğe ve askerlikten güvenlik şirketlerine kadar geniş bir yelpazede faaliyet göstermiştir. Döneminde ciddi tartışmalar yaratan söz konusu girişimlerin çok uluslu korporatist yapılara hizmet ettiği 
öne sürülmüş ve karanlık ithamların konusu olmuştur (Waite \& Waite, 2010: 81). Korporatist kültürün kendine has bazı özellikleri öne çıkmaktadır. Bunlar: kar amacının öncelenmesi, dar görüşlülük, yayılmacılık, hesap verme ve saydamlık eksikliği, salahiyet ve emperyal kibir olarak ifade edilmektedir (2010: 82-83). Korporatist şirketler, etkilerini çalışanlara doğru genişletirken açgözlü kurum/organizasyon özelliklerini benimsemektedirler. Başka bir ifadeyle, korporatist şirketler, çalışanları üzerinde mutlak bir hakimiyete sahiptir (2010: 83).

Bu yüzden korporatist yapının ne olduğunu ve neleri ifade ettiğini iyi kavramak gerekmektedir. Korporatist şirketler sadece zenginleşme amacı güden, bu amaç doğrultusunda her türlü yola başvuran sosyopat varlıklardır. Ayrıca, halkla ilişkilere potansiyel etkisi ve marka değeri dışında etik bağlamında bir anlayışa sahip değildir (Rushkoff, 2009: 18). Bundan dolayı, herhangi bir etik kaygı gütmemektedir ve bu anlayıştan yoksundur. Korporatizmin sorumlusu olarak her ne kadar küçük bir elitist kesim gösterilse de, bunun esas sorumlusu her birimizde içselleştirilen korporatizmin kendisidir. içselleştirdiğimiz bu anlayış dünyaya bakışımızı ve davranışlarımızı şekillendirmiştir. Daha da kötüsü, önceden var olan bir insanlık koşuluymuş gibi onun üzerimizdeki hâkimiyetini peşinen kabul etmekteyiz. Ancak bu, bizlere anlatıldığı gibi doğal bir sürecin sonucu değildir. Kökenleri Rönesans'a kadar uzanan, Sanayii Devrimiyle hızlanan ve topluma kararlı korporatist liderler tarafından daha iyi bir yaşam tarzı vaadiyle sunulan korporatizm, nihayetinde kitleleri tepeden kontrol etme konusunda başarıya ulaşmıştır (2009: 18). Korporatizm, insan doğası hakkında 20. yüzyıl faşizmiyle aynı entelektüel temel ve varsayımlara sahiptir. Dahası, faşist düzenlerde olduğu gibi özgür insanlara yönelik derin bir şüphe taşımaktadır. Velhasıl, faşizme gerek duyulmadan, kansız bir şekilde mutlak sosyal kontrolü sağlamanın kültür ve ticaret yoluyla olacağını uygulamaya koymuştur. Bu bağlamda korporatist yapının ve onun anlayışının, toplumun refah, değerler bütünü ve kimlik algısında merkeze oturtulmuş olması şaşırtıcı değildir (2009: 19).

Ingiliz filozof Bertrand Russell, ekonomik koşulların bireylerin özgürlüğü ve mutluluğunu sağlamak ve korumak amacıyla var olduğunu belirtmiştir. Modern kapitalizmin yaratmış olduğu korporatist yapılar gittikçe genişleyerek, yayılmaktadır ve bu konsantre kapitalist güç, devlet iradesinin kontrolü dışında sıradan insanların hayatlarını etkileyebilecek kararlar alabilmektedir (Carey \& Ongley, 2009: 53). Bu yüzden gücün demokratik kalabilmesi için devlet elinde toplanması gerekmektedir. Dolayısıyla, modern demokrasilerde sıradan bireylerin özgürlük ve mutluluklarını gözetecek etkili bir demok- 
rasi anlayışının devlet çatısı altında kurulması elzemdir (2009: 53). Russell'a göre büyük bir korporatist yapıda güç, mülkiyetten daha az yayılmaktadır, başka bir deyişle güç merkezde toplanmaktadır (Russell, 2009: 653). Buna ek olarak, şirketin büyüklüğü arttıkça, ortalama hissedarın çaresizliği de artmaktadır. Sonuç olarak, küçük yatırımcıların büyük korporatist yapılar içerisinde ezilmesi, güç odaklarının demokrasiyi alt etmelerinin ne denli kolay olduğunu göstermektedir. Bundan dolayı, ekonomik girişimlerin kontrolünün devlet gözetiminde olmaları ortalama vatandaş açısından büyük önem arz etmektedir çünkü büyük çaptaki sanayii gücünün dize getirilmesi için kamu mülkiyeti şarttır ancak mutlak suretle demokrasi ile tamamlanmalıdır (2009: 654-655). Bu bağlamda gelecekte, bireylerin büyük korporatist yapıların içerisinde yok olmaları sentetik iktidarın egemenliğine yol açacaktır. Sentetik iktidarın hâkimiyetinde ise küçük yatırımcıların korporatistlere karşı ezilmesinde olduğu gibi, bireyler muhatabının tam anlamıyla kim olduklarını bilmedikleri bir iktidara ezilmeye mahkûm olacaklardır. Sentetik iktidar, insanın robotlaşarak, siborglaşması ve ruhunu kaybetmesi ile ekonomik ve toplumsal anlamda ilişkilidir.

RoboCop'ta korporatist bir yapı olan OCP etik değerler anlamında kocaman bir soru işaretidir. ilk bakışta kamu güvenliğini gözetir gibi görünen $\mathrm{OCP}$, uzun vadede büyüme, genişleme ve egemenlik oluşturma planları gütmektedir. Ayrıca, ОСР açısından bireylerin özgürlüğü ve çalışanların güvenliği/iş güvencesi son derece muğlak konulardır. Bu tarz son derece hayati konuların şirket yöneticilerinin oportünist emellerine kurban edilmeyeceğinin herhangi bir garantisi yoktur. Bertrand Russell'ın ifade ettiği gibi OCP büyüdükçe ve güçlendikçe daha anti-demokratik bir yapıya dönüşecek ve kamu gücünü elinde toplayarak, sıradan vatandaşların hayatlarına totaliter müdahalelerde bulunabilecektir. Bu açıdan, ilk etapta olumlu fikir gibi görünen polis teşkilatının korporatist bir yapı olan OCP tarafından devralınmaSı, özünde oldukça tehlikeli ve anti-demokratik sonuçlar yaratabilecek türden bir olgudur. Bunu, korporatist faşizm olarak nitelemek yanlış olmayacaktır ve RoboCop tam olarak bunu anlatmak istemektedir.

RoboCop'ta korporatist faşizmin vücut bulmuş hali Dick Jones karakteridir. OCP'nin genel başkan yardımcısı Jones, yok edici bir hırsa sahip, oportünist ve yozlaşmış bir iş adamını temsil etmektedir. ${ }^{5}$ Jones, Makyavelci bir anlayışla hareket etmektedir ve gücü elde etmek için yapmayacağı eylem

\footnotetext{
${ }^{5}$ Ancak toplumun genel algısında bu faşist eğilimler gizlenmekte ve korporatist hegemonyanın kontrolünde suni bir kusursuz demokrasi ve özgürlükler imajı yaratılmaktadır.
} 
yoktur ki buna cinayet dâhildir. En büyük rakibi, Bob Morton'u çete lideri Clarence Boddicker'a ortadan kaldırtarak, OCP'nin yönetim kurulunda gücüne güç katmak istemektedir. Bu bağlamda Jones, basmakalıp korporatist bir iş adamıdır. Jones'un karanlık planlarını suya düşürecek olan ise RoboCop'un ta kendisidir. RoboCop, mental anlamda Murphy'e dönüştükten sonra olayları daha gerçekçi ve analitik yorumlama imkânına sahip olmuştur. Gerçekleri ve büyük resmi görmeyi başaran Murphy, Jones'un OCP'deki yozlaşmış düzenin yegâne sorumlusu olduğunun farkına varır ve onun yok edilmesine yönelik somut bir girişimde bulunur. Ayrıca, veri tabanında programlanmış olan dört direktifin gizli olan dördüncü direktifi, RoboCop, Jones'un peşine düştüğünde açığa çıkmaktadır: "OCP'nin kıdemli bir yöneticisini tutuklamaya yönelik herhangi bir girişim, kapatmaya neden olur" (Verhoeven, 1987: 1:10:16). Böylelikle, toplum güvenliğiyle ilgisi olmayan ve sadece OCP yöneticilerinin çıkarlarını gözeten bu direktif, ona gizlice enjekte edilmiştir. Ancak Murphy'e dönüşen RoboCop bunu sorgulayacak, onaylamayacak ve tam aksini yaparak Jones'u herkesin gözü önünde ortadan kaldıracaktır.

\section{Sonuç: Insanlığa Alternatif Bir Siborg Olarak RoboCop}

Paul Verhoeven'ın RoboCop yapımının alt-metninde geniş bir spektrumda sosyal, psikolojik ve felsefi meselelere değinilmektedir. Bunların arasında dehümanizasyon, insan hakları, emek, teknokapitalist korporatizm ve posthümanizm gibi konular öne çıkmaktadır. Ayrıca bu makalede ayrıntılı biçimde değinilmeyen tüketim toplumu, politika ve cinsiyet rolleri gibi konulara da filmde değinilmektedir. Örneğin, cinsiyet özelinde Murphy'nin partneri Lewis'in çekici bir kadın olmasına karşın, filmin hiçbir sahnesinde kadın kimliğiyle ön plana çıkmaması dikkat çekicidir. Lewis, kadından önce bir partnerdir ve diğer herkes gibi polis memurudur. Diğer konulardan da benzer örnekler verilebilmektedir.

RoboCop'u posthümanizm penceresinden incelediğimizde, nereden veya hangi açıdan bakılırsa bakılsın teknokapitalist korporatizm olgusuna takılı kalınmaktadır. İnsan sonrası bir figür olan RoboCop neden ve hangi amaç doğrultusunda yaratılmıştır? Onun, hangi amaçlarla yaratıldığı filmde doğrudan açıklanmasa da, bunun OCP'nin büyüme, tekelleşme ve piyasa haricinde kamu alanlarına da egemen olma hedefleriyle yakından ilişkili olduğu çıkarımı yapılabilmektedir. RoboCop örneğinde insan sonrası bir yaratım olan siborg, hümanist bir anlayıştan uzak bir noktada durmaktadır çünkü bir nesne ya da ürün olarak araçsallaştırılmaktadır. Araçsallaştırılan bu nesne insan karşıtı bir figür olarak insanlığın karşısında bir alternatif olarak sunulmaktadır. Insan sonrası yaklaşım açısından olumlu görülebilecek 
bu göndermeler RoboCop'ta açıkça vurgulanmaktadır. Filmde, insan adeta tüm sorunların merkezine oturtulmuş ve insanlık, eleştirinin odak noktasında konumlandırılmıştır. Öyle ki, tüm sömürü, şiddet, zulüm ve problemlerin kaynağı olarak insanlık gösterilmektedir. RoboCop bu sorunlara sebep olanlara bir alternatif olarak sunulmaktadır. Bir siborg olarak teknolojik gelişmişliğin dişında mental anlamda da insana alternatif olabilecek bir kapasiteye sahiptir. Ancak gelecekte birden çok siborg türünün var olmasıyla birlikte siborglar arasında, insanlar arasında olduğu gibi, eşitsizlikler ve tahakküm durumlarının ortaya çıkması muhtemeldir. Bu durumlar bazı siborg türlerinin, kendinden daha üstün özelliklere sahip olanlar tarafından köleleştirilmesine yol açabilecektir. Bunu önleyebilmek adına, tüm siborgların eşitliğini sağlayan yasalar düzenlenmeli ve uygulamaya konulmalıdır. Bu noktada insan sonrası bakış açısıyla siborglar, insanlar ve tüm canlılarla birlikte eşit bir pozisyonda konumlandırılmalı ve yaşayan tüm canlı türleriyle eşit haklara sahip olmalıdır.

Posthümanizm, hümanizme karşı duruş sergilerken antihümanizmle benzer bir noktada durmaktadır. Her iki hareket, evrensel hümanist retoriği terk eden bir anlayışı benimsemektedir ve hiyerarşik olmayan farklılık vurgusu yapmaktadır (Ferrando, 2019: 45). Bu anlamda, "posthümanizm ve antihümanizm insanlığa yönelik tekilci bir yaklaşım sergilemekten geri durmaktadır. Bu, kendi görüşünü, bakış açııını ve tecrübelerini tüm insanlığa dayatabilecek spesifik bir insan türünün olmaması anlamına gelmektedir" (2019: 45). Bu bağlamda, Batı felsefe tarihinin nesnel konusu olarak adlandırılanların evrensel insan deneyiminin beyaz, ataerkil ve batı-merkezci insan deneyimiyle aynı konumda bulunduğunu açığa vurmaktadır (2019: 45). Dolayısıyla, tarihi "nesnel” olarak tarif edenler, koydukları kriterlerin dışında kalanları, kadınlar ve Avrupalı olmayanlar gibi, kendi önyargı ve beklentileri doğrultusunda ele almışlardır (2019: 46).

Bu açıdan değerlendirildiğinde, RoboCop figürünün insana alternatif bir varlık olarak sunulduğunu görebilmekteyiz. İnsanlık, egemen ideoloji ve güç odaklarının içerisinde hiyerarşik ilişkilere maruz kalarak varlığını sürdürmektedir ancak RoboCop için aynı durum söz konusu değildir. İnsan sonrası bir varlık olan RoboCop, dil, din, ırk, ulus, cinsiyet, sınıf gibi hiyerarşik unsurlardan arınmış biçimde hareket etmektedir. Yasaları ne pahasına olursa olsun uygulayacak güce ve iradeye sahiptir. Bu anlamda insanların sağlayamadıkları ve sağlamalarının mümkün olmadığı tarafsız olabilme özelliğini (nötr) ortaya koyabilmiştir. Bu tarafsızlık sayesinde RoboCop istisnasız biçimde doğrulardan yana olmuş ve yanlışların karşısında durmuştur. Buna 
verilecek en güzel örneklerden biri, OCP'nin yöneticilerinden Dick Jones'u kirli ilişkilerinden dolayı toplantı esnasında herkesin gözü önünde vurmasıdır. Bu olayın alt metninde, RoboCop, diğer korporatist yöneticilere böylece gözdağı vermektedir. Kanun dışına çıkan, ezen ve haksızca sömüren kim olursa olsun, sonunun Jones gibi olacağı mesajını iletmektedir. Bu anlamda insan merkezci bir anlayışı terk eden RoboCop, insan sonrası ve nötr bir anlayışı benimsemektedir. Ferrando'nun ifadesiyle,

İnsan kavramının ve insanlığın tarihsel oluşumunun "sonrası"dır, her ikisi de daha önce gördüğümüz gibi hiyerarşik sosyal yapılara ve insan merkezli varsayımlara dayanmaktadır. Türcülük insan sonrası eleştirel yaklaşımın ayrılmaz yönünü oluşturmaktadır. Posthümanizm post-dışlayıcılık olarak da görülebilir: en geniş anlamıyla varoluşun uzlaşmasını sunan ampirik bir arabuluculuk felsefesidir. Posthumanism, postmodern yapısöküm uygulaması ile herhangi bir düalizm veya antitezi kullanmamakta, herhangi bir ontolojik kutuplaşmayı çözmemektedir (2013: 29).

Bu açıdan değerlendirildiğinde olumlu bir örnek olarak tasvir edilmektedir çünkü RoboCop insanlığı aşan ve ona alternatif bir vizyonun temsilcisidir. Ayrıca, posthümanizm insanlığı ve insanmerkezciliği aşmaya odaklanmaktadır (Braidotti, 2018: 7). Bunun bir sonucu olarak insanmerkezcilik kavramı, yerini post-insanmerkezciliğe bırakmıştır ve bu kavram yaşayan tüm türleri tek bir şemsiye altında birleştirmektedir (2018: 11).

Sonuç itibariyle, Murphy dehümanize edilmiş, siborg olarak diriltilmiş ancak korporatist bir güç olan OCP'nin hizmetinde kalmış ve bundan sıyrılamamıştır. Murphy'nin dehümanize edilmesi teknokapitalist korporatist güçlerin çalışanlara karşı giriştiği bir hamledir ve bu hamleyle tüm emekçi sınıfına dolaylı bir mesaj verilmektedir. Fakat OCP'nin uygulamaya koyduğu dehümanizasyon ters tepecektir çünkü insan sonrası bir varlık olarak ortaya çıkan RoboCop, OCP'nin hizmetinde olmasına rağmen onun korporatist anlayışına sahip değildir. Bu durum RoboCop ile OCP arasında gelecekte yaşanması muhtemel sorun ve çatışmaların habercisidir. Bu çatışmaların OCP tarafından fark edilerek bastırıması ise kuvvetli bir olasılıktır. Filmde, Alex Murphy'nin RoboCop'a geçirdiği dönüşüm sürecinde üç adet farklı kimlik ortaya çıkmıştır: Murphy (insan), RoboCop (Robot Murphy) ve RoboCop (Siborg Murphy) (Marsellus, 2017: 51). Filmin sonunda kendini Murphy olarak tanımlayan RoboCop, kaskını çıkarmış ve yüzünü, yani insani tarafıyla sembolik bir şekilde yüzleşmeyi seçmiştir. İnsan, makine, siborg üçlemesinde film, insan sonrası bir duruşu benimsemiş ve bir siborg prototipini temsil 
eden RoboCop'tan yana olmuştur. İnsan sonrası bağlamında RoboCop, (Siborg Murphy) insanlık ile robotik teknolojinin başarılı bir birleşimini teşkil etmektedir (2017: 56).

İronik biçimde, Verhoeven, filmin başlarında insanı makine olarak tasvir etmekte ve filmin ikinci yarısında ise bu durumu tersine çevirerek makineleşmiş insan vizyonunu sunmaktadır. Böylelikle, RoboCop, insan ve insan sonrasına dair önemli pek çok meseleyi sorgulatmaktadır. Sonuç olarak, insan sonrası bir anlatı olan RoboCop, alt metninde Verhoeven'ın özgün tarzı ve sosyo-politik mesajlarıyla donatılmış bir gelecek vizyonu aktarmaktadır. Salt teknolojik gelişmişlik ve otomasyon ile ilerleme sağlanmasının mümkün olmayacağını ima edilerek, korporatizm engelinin aşımasının gerekliliğine işaret edilmiştir. Filmde bulunan ironilerden en büyüğü ise insan sonrası bir varlık olan RoboCop'un, yaratıcısı olan OCP'nin değerlerine tamamen zıt bir anlayışı benimsemiş olmasıdır ve bu anlamda Robocop, posthümanizmin devrimci ruhuna sahip olmakla birlikte yaratıcısının geleceği açısından başlı başına bir tehdit oluşturmaktadır. Ancak sonuç itibariyle bu tehdit teoride sınırlı kalmıs ve korporatist hegemonyadan kurtulamayarak uygulamaya geçme şansını bulamamıştır.

\section{Kaynakça}

Althusser, Louis (2014). On the Reproduction of Capitalism: Ideology and Ideological State Apparatuses. New York: Verso Trade.

Braidotti, Rosi (2018). "A Theoretical Framework for the Critical Posthumanities". Theory, Culture \& Society, 36(6): 31-61.

Carey, Rosalind \& Ongley, John (2009). Historical Dictionary of Bertrand Russell's Philosophy. Lanham, MD: Scarecrow Press Inc.

Ferrando, Francesca (2013). "Posthumanism, Transhumanism, Antihumanism, Metahumanism, and New Materialisms". Existenz, 8(2): 26-32.

Ferrando, Francesca (2019). Philosophical Posthumanism. New York: Bloomsbury Publishing.

Gunkel, David (2000). "We are Borg: Cyborgs and the Subject of Communication". Communication Theory, 10(3): 332-357.

Haraway, Donna (2006). Siborg Manifestosu: Geç Yirminci Yüzyılda Bilim, Teknoloji ve Sosyalist-Feminizm. Çev. Osman Akınhay. İstanbul: Agora Kitaplığı. 
Haslam, Nick (2006). "Dehumanization: An Integrative Review". Personality and Social Psychology Review, 10(3): 252-264.

Kelly, Mark G. E. (2015). "Discipline is Control: Foucault contra Deleuze". New Formations, 84(84): 148-162.

Levi, Primo (1989). The Drowned and the Saved. New York: Simon \& Schuster.

Marsellus, Mynt (2017). “'The RoboCop We Deserve': Post-human Transformations and Social Critique in Paul Verhoeven's and Jose Padilha's RoboCop". Laurier Undergraduate Journal of the Arts, 3(3): 51-61.

Oliver, Sophie (2010). "Dehumanization: Perceiving the Body as (in) Human". Humiliation, Degradation, Dehumanization: Human Dignity Violated. Eds. Paulus Kaufmann and others. London \& New York: Springer, Science \& Business Media.

Rhee, Jennifer (2018). The Robotic Imaginary: The Human and the Price of Dehumanized Labor. Minneapolis: University of Minnesota Press.

Rushkoff, Douglas (2009). Life Inc.: How the World Became a Corporation and How to Take it Back. New York: Random House.

Russell, Bertrand (2009). The Basic Writings of Bertrand Russell. New York: Routledge.

Scanlan, James P. (1960). "Man as Laborer, Dehumanized". The Review of Politics, 22(2): 298-301.

Sobchack, Vivian C. (1997). Screening Space: The American Science Fiction Film. New Brunswick: Rutgers University Press.

Suarez-Villa, Luis (2012). Technocapitalism: A Critical Perspective on Technological Innovation and Corporatism. Philadelphia: Temple University Press.

Swartz, Jon (2015, March 14). "Protesters Stage Anti-Robot Rally at SXSW". https://www.usatoday.com/story/tech/2015/03/14/sxsw-robot-aiprotest-artificial-intelligence/24777871/. Retrieved January 4, 2021.

Verhoeven, Paul (Director) (1987). RoboCop [Motion picture]. USA: Orion Pictures.

Waite, Duncan \& Waite, Susan F. (2010). "Corporatism and its Corruption of Democracy and Education". Journal of Education and Humanities: Theory and Practice, 1(2): 81-106. 
Yigit, Tuncay and others (2018). "Robotics Rights and Ethics Rules". Journal of Multidisciplinary Developments, 3(1): 30-37.

“COPE-Dergi Editörleri İçin Davranış Kuralları ve En İyi Uygulama ilkeleri” çerçevesinde aşağıdaki beyanlara yer verilmiştir:

Teşekkür: Bu makalenin üretilmesine vesile olduğu için sayın Dr. Emrah Atasoy’a teşekkür ederim.

Etik Kurul Belgesi: Bu çalışma için etik kurul belgesi gerekmemektedir.

Çıkar Çatışması Beyanı: Bu makalenin araştırması, yazarlığı veya yayınlanmasıyla ilgili olarak yazarın potansiyel bir çıkar çatışması yoktur.

The following statements are made in the framework of "COPE-Code of Conduct and Best Practices Guidelines for Journal Editors":

Acknowledgment: I thank to Dr. Emrah Atasoy for helping produce this article.

Ethics Committee Approval: Ethics committee approval is not required for this study. Declaration of Conflicting Interests: The author has no potential conflict of interest regarding research, authorship or publication of this article. 